Int. J. Electrochem. Sci., 11 (2016) 10815 - 10826

International Journal of

ELECTROCHEMICAL

SCIENCE

www.electrochemsci.org

\title{
Fabrication of $\beta-\mathrm{MnO}_{2} / \mathrm{RGO}$ Composite and Its Electrochemical Properties
}

Lei Zhang ${ }^{1}$, Hongdong $\mathrm{Liu}^{2, *}$,Haibo Ruan ${ }^{2}$, Yongyao $\mathrm{Su}^{2}$, Rong $\mathrm{Hu}^{2}$, Liangliang Tian ${ }^{2}$, Zhongli $\mathrm{Hu}^{2}$, Jing $\mathrm{Li}^{2}$

${ }^{1}$ College of life science, Chongqing normal university, Chongqing 401331, PR China

${ }^{2}$ Research institute for new materials technology, Chongqing university of arts and sciences, Chongqing 402160, PR China

*E-mail: 1hd0415@126.com

doi: $10.20964 / 2016.12 .82$

Received: 25 September 2016 / Accepted: 19 October 2016 / Published: 10 November 2016

$\mathrm{MnO}_{2}$ is considered to be a promising alternative anode material for lithium ion batteries. In this work, $\beta-\mathrm{MnO}_{2} / \mathrm{RGO}$ composite has been successfully fabricated via hydrothermal method. The sample is carefully investigated by X-ray diffraction (XRD) techniques, Raman spectra, X-ray photoelectron spectroscopy (XPS) and scanning electron microscopy (SEM). When $\beta-\mathrm{MnO}_{2} / \mathrm{RGO}$ composite as anode material for lithium ion batteries, which shows good cycling performance and excellent rate capacity.

Keywords: $\mathrm{MnO}_{2}, \beta-\mathrm{MnO}_{2} / \mathrm{RGO}$ composite, lithium ion batteries, anode material

\section{FULL TEXT}

(C) 2016 The Authors. Published by ESG (www.electrochemsci.org). This article is an open access article distributed under the terms and conditions of the Creative Commons Attribution license (http://creativecommons.org/licenses/by/4.0/). 